\title{
Recent finds from the northern Mesopotamian city of Tell Brak
}

\author{
GeOFF EMBERLING \& HELEN MCDONALD*
}

Until recently it had been thought that the first large cities in Mesopotamia, of which Uruk is the best-known example, had developed on the alluvial plain of Sumer during the 4th millennium $\mathrm{BC}$. The discovery of a monumental building with a massive basalt threshold dating before the middle of the 4 th millennium (Oates \& Oates 1997) raised the question whether Brak might have been a city as large and complex as those of southern Mesopotamia. Subsequent topographic survey and a series of test pits has established that Brak was, at its largest, up to 100 ha in total area in the middle of the 4th millennium, well before any substantial southern influence at the site. We are now investigating the diversity of the city at this time.

Among the mid 4th-millennium buildings that have been identified up to now is a formal tripartite structure in which both the architecture and the large-scale cooking installations (including a substantial domed oven (FIGURE 1) and a heavily burnt mudbrick 'grill') suggest that this was not residential but was probably used for feasts, an interpretation reinforced by the large number of mass-produced pottery plates and the unusual faunal assemblage, with a relative abundance of hare bones, in the fills.

A contemporary residential area has produced a number of interesting finds, including a charming alabaster bear (FIGURE 2; Pittman 2002) which, together with three in situ Eye Idols and a number of stamp seals and amulets, provides a link between these recently excavated levels and the Grey Brick Stratum of the Eye Temple excavated by Mallowan in the 1930s, both now to be dated to the mid 4th millennium BC (Oates \& Oates 2002). Under the floor of one of the residential structures was found an astonishing cache of over 350 beads (FIGURE 3), predominantly carnelian but including gold, silver, lapis lazuli, amethyst and rock crystal. Traces of woven reeds indicated that the cache had originally been kept in some form of basket or bag. This level had been heavily burnt and the occupants were presumably unable to return to recover the beads.

Later in the 4th millennium the site was occupied by people from southern Mesopotamia. In one of their houses was found a unique artefact: a 'tablet' of fine clay with slots for 10 microlithic arrowheads (FIGURE 4; Wright 2002).

The project is also investigating the mid 3rdmillennium occupation of the site, when Brak (ancient Nagar) was one of the capital cities of Syria along with Ebla and Mari. Recent excavations have focused on a large building with a curving outer enclosure wall (FIGURE 5). The structure as so far excavated encompasses a large-scale bakery - with areas for grain storage, grinding flour and baking - as well as residential rooms. The bakery was burned and abandoned, leaving not only masses of burnt barley and wheat but large numbers of cylinder seal impressions which suggest that the activities carried out here were carefully regulated. The structure itself may be part of a larger administrative institution, perhaps a palace or a temple.

One striking find from this area is a clay model of a house or tower (FIGURE 6). The front has a tall door above which are three rows of birds perching on protruding roof beams while eight goat heads decorate the roof.

Acknowledgements. The Brak project, directed by David Oates with fundamental assistance from Joan Oates, and the authors as Field Directors, has been supported by the National Science Foundation (BCS-0107251), the British School of Archaeology in Iraq, the McDonald Institute for Archaeological Research, the British Academy and the Metropolitan Museum of Art. We are grateful to Dr Sultan Muhesen and Dr Abdul Razzaq Moaz, successive Directors-General of Antiquities and Museums, and their staffs, for their generous support and assistance.

\section{References}

AL-GAILANI WERR, L., et al. (ed.). 2002. Of pots and plans: papers presented to David Oates. London: NABU Publications.

EMBERLING, G. \& H. MCDONALD. 2001. Excavations at Tell Brak 2000: preliminary report, Iraq 63: 21-54.

OATES, J. \& D. OATES. 1997. An open gate: cities of the 4 th millennium BC (Tell Brak 1997), Cambridge Archaeological Journal 7: 287-307.

2002. The reattribution of Middle Uruk materials at Tell Brak, in E. Ehrenberg (ed.), Leaving no stones unturned: essays in honor of Donald P. Hansen: 145-54. Winona Lake (IN): Eisenbrauns.

PITTMAN, H. 2002. Bears at Brak, in al-Gailani Werr et al. (ed.): $287-96$.

WRIGHT, H.T. 2002. Arrows and arrowheads in the Uruk World, in al-Gailani Werr et al. (ed.): 373-8.

\footnotetext{
* Emberling, 1306 Wells Street, Ann Arbor MI 48104, USA. geoffe@umich.edu McDonald, McDonald Institute for
} Archaeological Research, University of Cambridge, Downing Street, Cambridge CB2 3ER, England.

ANTIQUITY 76 (2002): 949-50 

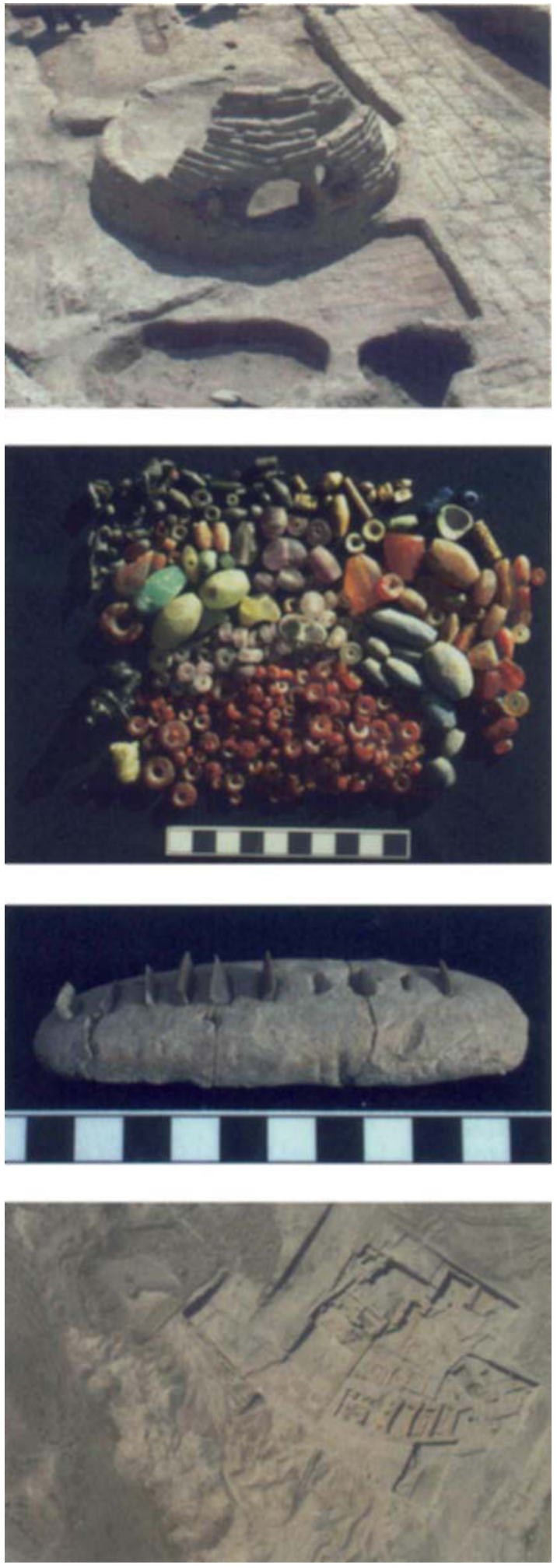

FIGURE 1 (left, top). Domed oven in a formal 'feasting' building of the mid 4th millennium $B C$.

FIGURE 2 (right, top). Alabaster bear figurine, ht $9 \mathrm{~cm}$, mid 4th millennium $B C$. Traces of red and black pigment survive on the head and claws.

FIGURE 3 (left). Beads from the cache found beneath a residential building of the mid 4th millennium $B C$.

FIGURE 4 (left). Clay 'tablet' with microlithic arrowheads, Late Uruk house, c. 3400 BC.

FIGURE 5 (left, bottom). Kite photograph taken in 2001 by Evan

Malone, Area TC (excavated area approximately $50 \times 80 \mathrm{~m}$ ).

FIGURE 6 (right, bottom).

Pottery house or tower model, ht 43 $\mathrm{cm}$, late $3 \mathrm{rd}$ millennium $B C$, Area TC.
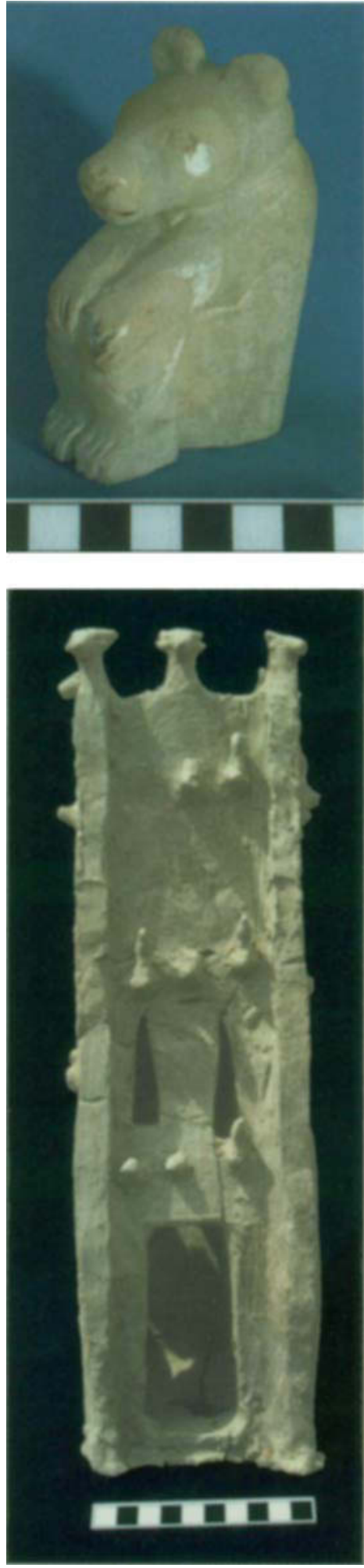